\section{JURNAL EKONOMI EFEKTIF}

ISSN : $2622-8882$, E-ISSN : 2622-9935

Jurnal Ekonomi Efektif, Vol. 3, No. 2, Januari 2021 @Prodi Manajemen Fakultas Ekonomi Universitas Pamulang

\title{
PENGARUH PROSES SELEKSI TERHADAP KINERJA KARYAWAN PADA PT. SECURE PARKING UNIT SUPERINDO DI TANGERANG
}

\author{
Abdul Rahman Safiih \\ Universitas Pamulang, Tangerang Selatan, Banten, Indonesia \\ dosen02457@unpam.ac.id
}

Manuskrip: Nov-2020; Ditinjau: Nov-2020; Diterima: Des-2020; Online: Jan-2021; Diterbitkan: Jan-2021

\begin{abstract}
ABSTRAK
Penelitian ini bertujuan untuk mengetahui pengaruh proses seleksi terhadap kinerja karyawan pada PT. Secure Parking Unit Superindo di Tangerang. Metode yang digunakan adalah explanatory research dengan sampel sebanyak 82 responden. Teknik analisis menggunakan analisis statistik dengan pengujian regresi, korelasi, determinasi dan uji hipotesis. Hasil penelitian ini variabel proses seleksi diperoleh nilai rata-rata skor sebesar 3,416 dengan kriteria baik. Variabel kinerja karyawan diperoleh nilai rata-rata skor sebesar 3,790 dengan kriteria baik. Proses seleksi berpengaruh positif dan signifikan terhadap kinerja karyawan dengan nilai persamaan regresi $\mathrm{Y}=12,028+0,766 \mathrm{X}$, dan nilai koefisien korelasi 0,746 atau memiliki tingkat hubungan yang kuat dengan nilai determinasi 55,6\%. Uji hipotesis diperoleh signifikansi $0,000<0,05$.
\end{abstract}

Kata Kunci: Proses Seleksi, Kinerja Karyawan.

\begin{abstract}
This study aims to determine the effect of the selection process on employee performance at PT. Secure Parking Unit Superindo in Tangerang. The method used is explanatory research with a sample of 82 respondents. The analysis technique uses statistical analysis with regression testing, correlation, determination and hypothesis testing. The results of this research variable selection process obtained an average score of 3,416 with good criteria. Employee performance variables obtained an average score of 3,790 with good criteria. The selection process has a positive and significant effect on employee performance with the regression equation $Y=12.028+0.766 X$, and the correlation coefficient value of 0.746 or having a strong level of relationship with a determination value of 55.6\%. Hypothesis testing obtained a significance of $0.000<0.05$.
\end{abstract}

Keywords: Selection Process, Employee Performance. 


\section{PENDAHULUAN}

\section{A. Latar Belakang Masalah}

Sumber daya Manusia merupakan bagian cukup penting dalam pencapaian suatu tujuan organisasi, baik itu perusahaan besar maupun perusahaan kecil. Suatu perusahaan memiliki peralatan yang modern dengan teknologi tinggi, manusia merupakan motor pengerak, tanpa manusia suatu perusahaan tidak akan berfungsi. Tujuan memahami dan mempelajari manajemen sumberdaya manusia sebagai suatu pengetahuan yang di perlukan untuk memiliki kemampuan analisa dalam menghadapi masalah - masalah manajemen sumber daya manusia khususnya bidang operasioanal.

Dalam menghadapi arus globalisasi sumber daya manusia (SDM) memegang peranan yang sangat dominan dalam aktivitas atau kegiatan perusahaan. Berhasil atau tidaknya perusahaan dalam mencapai tujuan yang ditetapkan sebelumnya sangat tergantung pada kemampuan sumber daya manusianya (Karyawan) dalam menjalankan tugas-tugas yang diberikan kepadanya.

Salah satu aktivitas dalam pengelolaan SDM adalah Proses Seleksi Karyawan. Proses Seleksi adalah suatu proses pengumpulan sejumlah pelamar yang memiliki kualifikasi yang sesuai dengan yang dibutuhkan perusahaan, untuk dipekerjakan dalam perusahaan menurut Mathis (2010:103). Manfaat dari Proses seleksi adalah memiliki fungsi sebagai "the Right Man on The Right Place", dimana hal ini menjadi pegangan bagi para manager dalam menempatkan tenaga kerja yang ada di perusahaannya.

Proses seleksi merupakan serangkaian aktivitas untuk mencari dan memikat pelamar kerja dengan motivasi, kemampuan, keahlian dan pengetahuan yang diperlukan guna menutupi kekurangan yang diidentifikasi dalam perencanaan kepegawaian. Sedangkan seleksi merupakan proses pemilihan dari sekelompok pelamar atau orangorang yang memenuhi kriteria untuk menempati posisi yang tersedia berdasarkan kondisi yang ada pada perusahaan. PT. Securindo Packatama Indonesia Unit Superindo Tangerang adalah perusahaan yang bergerang di dalam pengelolaan jasa perparkiran yang sudah berdiri sejak tahun 1979 di Sydney Australia, Di Indonesia, Secure Parking telah melayani negeri ini sejak tahun

1992 dan telah memiliki lokasi parkir dalam operasional sebanyak 400 lokasi yang tersebar di beberapa kota besar di Indonesia, yakni Jabodetabek, Bandung, Yogyakarta, Surabaya, Malang, Medan, Batam, Pekan baru, Palembang, Manado dan Jambi dengan total pengelolaan lebih dari 800.000 petak parkir dan didukung oleh lebih dari 12.000 putra putri Indonesia terpilih \& terlatih.

Pengelolaan sumber daya manusia sangat diperlukan untuk efektivitas sumber daya manusia dalam suatu organisasi. Tujuan dari hal tersebut adalah untuk memberikan kepada organisasi satuan kerja yang efektif untuk mencapai tujuan studi tentang manajemen perusahaan bagaimana seharusnya perusahaan dapat mengembangkan, menggunakan dan memelihara karyawan dalam kualitas dan kuantitas yang tetap.

Oleh karena itu pihak manajemen perusahaan harus mampu memahami bagaimana cara terbaik dalam mengelola karyawan yang berasal dari latar belakang, keahlian, dan kemampuan yang berbeda-beda sehingga karyawan dapat bekerja sesuai dengan keahlian dan jenis pekerjaan yang diberikan.

Penyusutan pegawai yang terjadi biasanya karena adanya pegawai yang memasuki masa pensiun, meninggal dunia atau dikeluarkan dari institusi karena melakukan pelanggaran tata tertib disiplin yang telah ditetapkan oleh PT. Secure Parking Unit Superindo Oleh karena itu pegawai baru yang akan menggantikannya akan memiliki masa kerja yang berbeda-beda. Rekrutmen juga dapat dilakukan untuk menambah 
pegawai baru kedalam suatu satuan kerja yang kegiatannya menuntut aktivitas yang tinggi. Dalam proses seleksi juga memerlukan adanya proses seleksi yang efektif, hal ini dilakukan untuk melakukan pemerataan pegawai sehingga kekuatan SDM yang dimiliki menjadi lebih seimbang.

Kegagalan dalam melakukan sistem seleksi tenaga kerja akan berdampak pada proses pencapaian tujuan perusahaan. Dimana kinerja dari PT. Secure Parking Superindo di Tangerang tidak hanya melayani sistem perparkiran di Mall Summarecon Digital Center, namun juga mampu menjaga kesinambungan dan memberikan pelayanan yang baik bagi konsumen.

Mengingat sangat pentingnya proses seleksi bagi perusahaan. Diharapkan dengan adanya proses seleksi yang baik dan efektif akan berdampak pada perkembangan perusahaan kedepannya untuk memperoleh sumber daya yang berkualitas di PT. Secure Parking Unit Superindo.

Berdasakan uraian diatas maka penulis tertarik untuk melakukan penelitian dengan judul: "Pengaruh Proses Seleksi Terhadap Kinerja Karyawan Pada PT. Secure Parking Unit Superindo di Tangerang".

\section{B. Rumusan Masalah}

1. Bagaimana proses seleksi pada PT. Secure Parking Unit Superindo di Tangerang?.

2. Bagaimana kinerja karyawan pada PT. Secure Parking Unit Superindo di Tangerang ?.

3. Adakah pengaruh antara proses seleksi terhadap kinerja karyawan pada PT. Secure Parking Unit Superindo di Tangerang?.

\section{Tujuan Penelitian}

1. Untuk mengetahui kondisi proses seleksi pada PT. Secure Parking Unit Superindo di Tangerang.

2. Untuk mengetahui kondisi kinerja karyawan pada PT. Secure Parking Unit Superindo di Tangerang.

3. Untuk mengetahui pengaruh antara proses seleksi terhadap kinerja karyawan pada PT. Secure Parking Unit Superindo di Tangerang.

\section{METODE PENELITIAN}

\section{Populasi}

Populasi dalam penelitian ini berjumlah 82 responden PT. Secure Parking Unit Superindo

\section{Sampel}

Teknik pengambilan sampling dalam penelitian ini adalah sampel jenuh, dimana semua anggota populasi dijadikan sebagai sampel. Dengan demikian sampel dalam penelitian ini sampel yang digunakan berjumlah 82 responden.

\section{Jenis Penelitian}

Jenis penelitian yang dipakai adalah asosiatif, dimana tujuannya adalah untuk mengetahui atau mencari keterhubungan antara variabel independen terhadap variabel dependennya

\section{Metode Analisis Data}

Dalam menganalisis data digunakan uji validitas, uji reliabilitas, analisis regresi linier sederhana, analisis koefisien korelasi, analisis koefisien determinasi dan pengujian hipotesis. 


\section{HASIL PENELITIAN DAN PEMBAHASAN}

\section{Analisis Deskriptif}

Pada pengujian ini digunakan untuk mengetahui skor minimum dan maksimum skor tertinggi, ratting score dan standar deviasi dari masing-masing variabel. Adapun hasilnya sebagai berikut:

Tabel 1. Hasil Analisis Descriptive Statistics

Descriptive Statistics

\begin{tabular}{lr|r|r|r|r} 
& N & Minimum & Maximum & Mean & \multicolumn{1}{c}{ Std. Deviation } \\
\hline Proses seleksi (X) & 82 & 28 & 44 & 34.16 & 3.936 \\
\hline Kinerja Karyawan (Y) & 82 & 29 & 49 & 37.90 & 4.045 \\
\hline Valid N (listwise) & 82 & & & & \\
\hline
\end{tabular}

Proses seleksi diperoleh varians minimum sebesar 28 dan varians maximum 44 dengan ratting score sebesar 3,416 dengan standar deviasi 3,936. Skor ini termasuk pada rentang sakala 3,40 - 4,19 dengan kriteria baik atau setuju.

Kinerja karyawan diperoleh varians minimum sebesar 29 dan varians maximum 49 dengan ratting score sebesar 3,790 dengan standar deviasi 4,045. Skor ini termasuk pada rentang sakala 3,40 - 4,19 dengan kriteria baik atau setuju.

\section{Analisis Verifikatif.}

Pada analisis ini dimaksudkan untuk mengetahui pengaruh variabel independen terhadap variabel dependen. Adapun hasil pengujian sebagai berikut:

\section{a. Analisis Regresi Linier Sederhana}

Uji regresi ini dimaksudkan untuk mengetahui perubahan variabel dependen jika variabel independen mengalami perubahan. Adapun hasil pengujiannya sebagai berikut:

Tabel 2. Hasil Pengujian Regresi Linier Sederhana

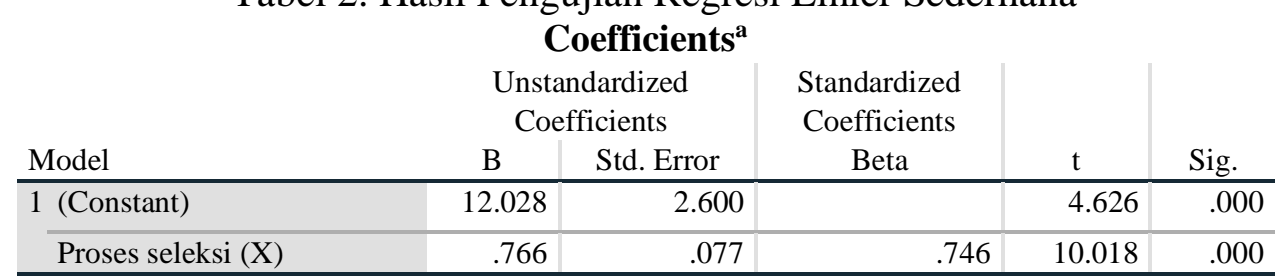

Berdasarkan hasil pengujian pada tabel di atas, diperoleh persamaan regresi $\mathrm{Y}$ $=12,028+0,766 \mathrm{X}$. Dari persamaan tersebut dijelaskan sebagai berikut:

1) Konstanta sebesar 12,028 diartikan jika proses seleksi tidak ada, maka telah terdapat nilai kinerja karyawan sebesar 12,028 point.

2) Koefisien regresi proses seleksi sebesar 0,766, angka ini positif artinya setiap ada peningkatan proses seleksi sebesar 0,766 point maka kinerja karyawan juga akan mengalami peningkatan sebesar 0,766 point.

\section{b. Analisis Koefisien Korelasi}

Analisis koefisien korelasi dimaksudkan untuk mengetahui tingkat kekuatan hubungan dari variabel independen terhadap variabel dependen. Adapun hasil pengujian sebagai berikut: 
Tabel 3. Hasil Pengujian Koefisien Korelasi Proses seleksi Terhadap Kinerja Karyawan.

Correlations $^{\text {b }}$

\begin{tabular}{llr|r} 
& & $\begin{array}{c}\text { Proses seleksi } \\
(\mathrm{X} 1)\end{array}$ & $\begin{array}{r}\text { Kinerja Karyawan } \\
(\mathrm{Y})\end{array}$ \\
\hline Proses seleksi (X) & Pearson Correlation & 1 & $.746^{* *}$ \\
\cline { 2 - 4 } & Sig. (2-tailed) & & .000 \\
\hline Kinerja Karyawan (Y) & Pearson Correlation & $.746^{* *}$ & 1 \\
\cline { 2 - 4 } & Sig. (2-tailed) & .000 & \\
\hline
\end{tabular}

Berdasarkan hasil pengujian diperoleh nilai korelasi sebesar 0,746 artinya proses seleksi memiliki hubungan yang kuat terhadap kinerja karyawan.

\section{c. Analisis Koefisien Determinasi}

Analisis koefisien determinasi dimaksudkan untuk mengetahui besarnya persentase pengaruh dari variabel independen terhadap variabel dependen. Adapun hasil pengujian sebagai berikut:

Tabel 4. Hasil Pengujian Koefisien Determinasi Proses seleksi Terhadap Kinerja Karyawan.

\section{Model Summary}

\begin{tabular}{lr|r|r|rr} 
& & & \multicolumn{2}{c}{} & \multicolumn{2}{c}{$\begin{array}{c}\text { Std. Error of the } \\
\text { Estimate }\end{array}$} \\
\hline 1 & $\mathrm{R}$ & \multicolumn{2}{c|}{ R Square } & Adjusted R Square & 2.711 \\
\hline
\end{tabular}

Berdasarkan hasil pengujian diperoleh nilai determinasi sebesar 0,556 artinya proses seleksi memiliki kontribusi pengaruh sebesar 55,6\% terhadap kinerja karyawan, sedangkan sisanya sebesar $44,4 \%$ dipengaruhi oleh faktor lain yang tidak dilakukan penelitian.

\section{d. Uji Hipotesis}

Pengujian hipotesis dengan uji t digunakan untuk mengetahui hipotesis mana yang diterima. Rumusan hipotesis: Terdapat pengaruh yang signifikan antara proses seleksi terhadap kinerja karyawan.

Tabel 5. Hasil Uji Hipotesis Proses seleksi Terhadap Kinerja Karyawan.

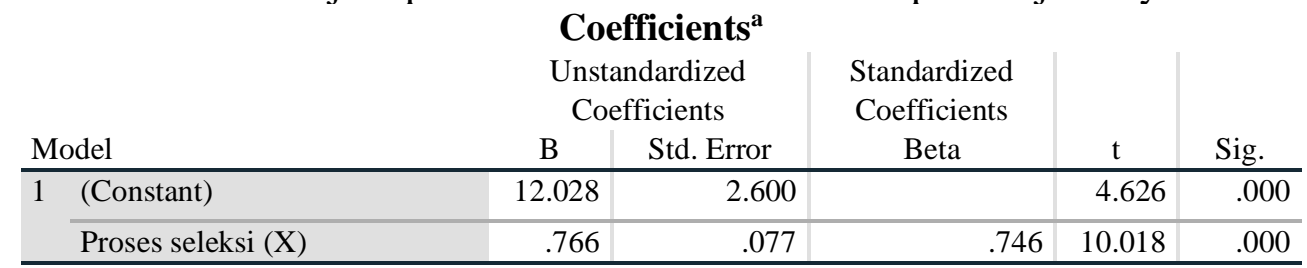

Berdasarkan hasil pengujian pada tabel di atas, diperoleh nilai t hitung $>\mathrm{t}$ tabel atau $(10,018>1,990)$, dengan demikian hipotesis yang diajukan bahwa terdapat pengaruh yang signifikan atara proses seleksi terhadap kinerja karyawan diterima.

\section{PEMBAHASAN HASIL PENELITIAN}

\section{Kondisi Jawaban Responden Variabel Proses seleksi}

Berdasarkan jawaban responden, variabel proses seleksi diperoleh ratting score sebesar 3,416 berada di rentang skala 3,40 - 4,19 dengan kriteria baik atau setuju.

\section{Kondisi Jawaban Responden Variabel Kinerja Karyawan}

Berdasarkan jawaban responden, variabel kinerja karyawan diperoleh ratting score sebesar 3,790 berada di rentang skala 3,40-4,19 dengan kriteria baik atau setuju. 


\section{Pengaruh Proses seleksi Terhadap Kinerja Karyawan}

Proses seleksi berpengaruh signifikan terhadap kinerja karyawan dengan persamaan regresi $\mathrm{Y}=12,028+0,766 \mathrm{X}$, nilai korelasi sebesar 0,746 atau memiliki hubungan yang kuat dengan kontribusi pengaruh sebesar 55,6\%. Pengujian hipotesis diperoleh nilai t hitung $>\mathrm{t}$ tabel atau $(10,018>1,990)$. Dengan demikian hipotesis yang diajukan bahwa terdapat berpengaruh signifikan antara proses seleksi terhadap kinerja karyawan diterima.

\section{PENUTUP}

\section{Kesimpulan}

a. Variabel proses seleksi diperoleh ratting score sebesar 3,416 berada di rentang skala 3,40 - 4,19 dengan kriteria baik atau setuju.

b. Variabel kinerja karyawan diperoleh ratting score sebesar 3,790 berada di rentang skala 3,40 - 4,19 dengan kriteria baik atau setuju.

c. Proses seleksi berpengaruh signifikan terhadap kinerja karyawan dengan persamaan regresi $\mathrm{Y}=12,028+0,766 \mathrm{X}$, nilai korelasi sebesar 0,746 atau kuat dan kontribusi pengaruh sebesar $55,6 \%$ sedangkan sisanya sebesar $44,4 \%$ dipengaruhi faktor lain. Uji hipotesis diperoleh nilai $t$ hitung $>\mathrm{t}$ tabel atau $(10,018>1,990)$.

\section{Saran}

a. Proses Seleksi bertujuan untuk mengisi jabatan karyawan yang kosong Hendaknya dalam proses seleksi HRD dapat lebih memperhatikan pengetahuan dan keterampilan yang telah memenuhi standar karyawan.

b. Proses seleksi dapat memberikan pengetahuan dan keterampilan yang telah memenuhi standar yang diharapkan.

\section{DAFTAR PUSTAKA}

Abdullah, M (2014) Manajemen dan Evaluasi Kinerja Karyawan, Yogyakarta: Penerbit Aswaja Pressindo.

Abdurrahman, Fathoni. 2006, Manajemen sumber daya manusia. Jakarta: PT Rineka Cipta.

Akbar, Irfan Rizka,. (2018) Analisis Kebijakan Kepala Sekolah Dalam Upaya Meningkatkan Kompetensi Guru (Study Kasus Pada Smk Muhammadiyah Parung). Masters thesis, Universitas Pamulang.

Algifari. (2015). “Analisis Regresi untuk Bisnis dan Ekonomi”. Yogyakarta: BPFE.

Arikunto, Suharsimi (2014). "Prosedur Penelitian Suatu Pendekatan Praktek". Jakarta: Rineka Cipta.

Bangun, Wilson. 2012. "Manajemen Sumber Daya Manusia”. Jakarta: Erlangga

Bejo Siswanto (2013) Manajemen Tenaga Kerja Rancangan dalam Pendayagunaan dan

Pengembangan Unsur Tenaga Kerja", Bandung: Sinar Baru.

Cangara Hafied. Pengantar Ilmu Komunikasi. PT. Raja Grafindo Persada Jakarta. 2006.

Edi Sutrisno (2016). Manajemen Sumber Daya Manusia. Jakarta: Prenadamedia Group.

Edwin B. Flippo. 2010 Personel Management (Manajemen Personalia), Edisi Vii

Fathullah . Komunikasi, etika, dan Hubungan Antar Manusia. Duta Nusindo: Semarang. 2007

Gary Dessler (2008). Human Resource Management. New Jersey : Prentice Hall, Tenth Edition

George Terry R \& Rue, Leslie W. Rue (2016) Dasar-Dasar Manajemen, Jakarta Bumi Aksara. 
Gerry Dessler (2016) Human Resources Management, Prenticehall, London: International Inc.

Gibson, James L; John M. Ivancevich; James H. Donnelly, Jr. 2010, Organisasi perilaku struktur proses. Jakarta: Erlangga.

Handoko (2016) Manajemen Personalia dan Sumberdaya Manusia. Yogyakarta: BPFE.

Handoko T. Hani, (2012), Manajemen Personalia dan Sumber Daya Manusia, edisi kedua, BPFE, Yogyakarta

Hasibuan, Malayu S.P. (2016). Manajemen Sumber Daya Manusia. Edisi Revisi. Jakarta: PT Bumi Aksara.

Imam Ghozali (2017). “Aplikasi Analisis Multivariate Dengan Program SPSS”. Edisi Kelima. Semarang: Badan Penerbit Undip.

Istijanto (2014) "Riset Sumber Daya Manusia". Jakarta: PT. Gramedia Pustaka

Jasmani, J., \& Sunarsi, D. (2020). The Influence of Product Mix, Promotion Mix and Brand Image on Consumer Purchasing Decisions of Sari Roti Products in South Tangerang. PINISI Discretion Review, 1(1), 165-174.

Kharis, Ismu Fadli (2011). "Studi Mengenai Impulse Buying dalam Penjualan

Luthans Fred (2014) Organizational Behavior, Ney York: McGraw-Hill, New York.

Mangkunegara, Prabu Anwar. (2016). Evaluasi Kinerja SDM. Cetakan ke tujuh, PT Refika Aditama: Bandung.

Prabawa ( 2013 ). Pengaruh Komunikasi Organisasi dan Gaya Kepemimpinan Terhadap Kinerja Karyawan dengan Budaya Organisasi sebagai Variabel Intervening, UIN. Jakarta.

Prawirosnetono. 2009. Kebijakan Kinerja Karyawan. Yogyakarta : BPFE

Robbins, P.S, \& Judge, A.T. (2003). Organizational Behavior. Jakarta: Salemba Empat.

Rozi, A., Agustin, F., Hindriari, R., Rostikawati, D., \& Akbar, I. R. (2020). The Effect Of Leadership On Employee Performance at PT. Stella Satindo In Jakarta. HUMANIS (Humanities, Management and Science Proceedings), 1(1).

Santoso, Singgih (2015). "Menguasai Statistik Multivariat". Jakarta: PT Elex Media Komputindo.

Sarwani, S., Akbar, I. R., Handoko, A. L., \& Ilham, D. (2020). Pengaruh Pelatihan dan Motivasi terhadap Produktivitas Kerja Karyawan pada PT. Lion Mentari Airlines Bandara Internasional Soekarno Hatta Cengkareng. Jurnal Ilmu Komputer dan Bisnis, 11(2a), 91-100.

Sedarmayanti (2016) Manajemen Sumber Daya Manusia, Reformasi Birokrasi dan Manajemen Karyawan Negeri Sipil, Cetakan Kelima, Bandung: PT Refika Aditama.

Sudjana (2014) "Metode Statistika", Bandung: Tarsido.

Sugiyono (2017), "Metode Penelitian Administrasi : dilengkapi dengan Metode R \& D". Bandung: Alfabeta.

Suharsimi, Arikunto, 2010. Prosedur Penelitian Suatu Pendekatan Praktek, Jakarta: Penerbit Rineka Cipta.

Suhartanto (2014). "Metode Riset Pemasaran". Bandung: Alfabeta

Sunarsi, D., Akbar, I. R., Prasada, D., Kristianti, L. S., Muliani, H. S., Anjayani, N. S., \& Hendra, H. (2020). Pengaruh Kompetensi dan Pengembangan Karir terhadap Kinerja Karyawan pada PT. Berkah Cemerlang di Jakarta. Jurnal Ilmu Komputer dan Bisnis, 11(2), 2465-2472.

Veithzal Rivai (2015) Manajemen Sumber Daya Manusia Untuk Perusahaan, Jakarta: Raja Grafindo Persada.

Wibowo (2015) Manajemen Kinerja, Jakarta: PT. Raja Grafindo Persada. 